\author{
Abstracta Iranica \\ Abstracta Iranica Revue bibliographique pour le domaine irano-aryen \\ Volume 34-35-36 | 2017 \\ Comptes rendus des publications de 2011-2013
}

\title{
Rüdiger Schmitt. Astarte, Mistress of Horses, Lady of the Chariot: The Warrior Aspect of Astarte
}

\section{Astrid Nunn}

\section{(2) OpenEdition}

Journals

Édition électronique

URL : http://journals.openedition.org/abstractairanica/41215

DOI : 10.4000/abstractairanica.41215

ISSN : 1961-960X

Éditeur :

CNRS (UMR 7528 Mondes iraniens et indiens), Éditions de l'IFRI

\section{Référence électronique}

Astrid Nunn, "Rüdiger Schmitt. Astarte, Mistress of Horses, Lady of the Chariot: The Warrior Aspect of Astarte », Abstracta Iranica [En ligne], Volume 34-35-36 | 2017, document 97, mis en ligne le 15 juillet 2016, consulté le 26 septembre 2020. URL : http://journals.openedition.org/abstractairanica/41215 ; DOI : https://doi.org/10.4000/abstractairanica.41215

Ce document a été généré automatiquement le 26 septembre 2020.

Tous droits réservés 


\title{
Rüdiger Schmitt. Astarte, Mistress of Horses, Lady of the Chariot: The Warrior Aspect of Astarte
}

\author{
Astrid Nunn
}

\section{RÉFÉRENCE}

Rüdiger Schmitt. « Astarte, Mistress of Horses, Lady of the Chariot: The Warrior Aspect of Astarte ». Die Welt des Orients, 43/2, 2013, p. 213-225.

1 Astarté est connue comme étant la déesse de la fertilité et de la guerre. En réalité, au Bronze récent, elle était, un peu comme Anat, surtout une déesse de la guerre, de la magie et de la guérison. Ce sont ces fonctions qui furent adoptées par l'Egypte du Nouvel Empire. Le caractère militaire d'Astarté sera moins évident au I ${ }^{\mathrm{er}}$ mill., pendant lequel elle sera surtout une déesse de la royauté et guérisseuse.

\section{AUTEURS}

\section{ASTRID NUNN}

Université de Munich 